\title{
Local referendum and assembly of municipality inhabitants in the Slovak Republic ${ }^{1}$
}

\author{
PhDr. Tomáš ALMAN, PhD.
}

\begin{abstract}
The paper deals with the local referendum and assembly of municipality inhabitants as the forms of direct democracy under the conditions of the Slovak Republic. The paper pays the special attention to highlighting the legal and application problems connected with these institutions in the Slovak Republic. The problems are caused especially by the legal regulation which is terse in its content, unambiguous and essentially incorrect, what, in the end, influences the exercise of local self-government. The aim of the paper is to identify the position of local referendum and assembly of municipality inhabitants as the form of exercise of local self-government, along with other forms, through the analysis of respective scientific literature, legal regulations and other sources and I will try to highlight the specific lacks mainly in the legal regulation, to evaluate the situation and to provide some suggestions and solutions.
\end{abstract}

\section{Keywords}

local referendum, assembly of municipality inhabitants, municipal self-government, direct democracy

\section{Introduction}

The given paper is content-oriented to the legal and application problems of local referendum and assembly of municipality inhabitants as the forms of direct democracy in the Slovak republic. The paper pays a special attention to highlighting the functions of self-government, the democracy principle within the given forms and, by analogy, to express their nature and significance. I will follow these institutions from the point of view of the current public administration in the Slovak Republic, from the constitutional point of view and with regard to the focus of the mentioned grant (VEGA grant project: 1/0340/17 Forms of Implementation of municipal self-government), not from a historical and political point of view or from a theoretical point of view. Thus, the target focus of the paper has several lines that determine a formulation of the content and structure. In addition to above men-

1 The paper was elaborated as part of the VEGA grant project: 1/0340/17 Forms of Implementation of municipal self-government. 
tioned, after the evaluation of the problems detected, the paper will focus on the possible solutions of making both, the local referendum and assembly of municipality inhabitants, functioning in order to guarantee the relevant participation in governance from the part of a municipality inhabitants as well as general public.

\section{The constitutional departures of local referendum and a municipal inhabitants' assembly}

The essence of self-government as a whole, including the local self-government ${ }^{2}$, is autonomy. However, this autonomy is not based on an absolute wilfulness, it always must be within the framework of the legally defined remit. It is possible to identify common features such as collective decision making, majority rule, citizenship rights, easier organization (in small entities), savings of finances, close interconnection of the inhabitants and problem etc. Differences we find in the organization, the opportunity to present, the exclusion of the debate (referendum). Similar conclusions can be found in several works. ${ }^{3}$

However various forms the decision-making may have, the intended target should be the same. The main purpose of the decision-making should be a chance of the largest possible number of subjects (a municipality inhabitants) to participate in the exercise of self-government and thus to properly ensure the public good and the municipality development. Similar starting points and theses are also found in the European Charter of Local Self-Government or the Venice Commission' Code of Good Practice on Referendums. The first mentioned international document contains key ideas in the preamble or in the individual articles. For example based on the Art. 3 "local self-government denotes the right and the ability of local authorities, within the limits of the law, to regulate and manage a substantial share of public affairs under their own responsibility and in the interest of local population." The significance and essence of the forms of direct democracy under examination are, according to my opinion, emphasized also by a "higher" legitimacy, since the historical context and social development confirmed the cardinal position of direct forms of democracy at the legitimacy of taking the principal decisions that are connected with the interests of a local society. The given trend is confirmed especially at the level of a municipality, the forms of local direct democracy are logically more easily feasible within a smaller territory, what demonstrates the immediacy and interconnection of the exercise of self-government and the rights and interests of inhabitants of those territorial units. ${ }^{4}$

The local referendum and assembly of inhabitants are undoubtedly the institutes of general significance in which the above mentioned functions and especially the democratic principle are coupled. Therefore, the local referendum and assembly of municipality inhabitants as the forms of direct democracy under the conditions of the Slovak Republic should have the proper significance, legal status and weight, legal protection and, in particular, the precision constitutional regulation. First of all, the last mentioned reproach is confirmed by the application practice, since many problems arise in this sphere and on its basis.

2 Local self-government in the following meaning also as municipal self-government.

3 For example in KROUSE, Richard W.: Polyarchy \& Participation: The Changing Democratic Theory of Robert Dahl, in: Polity, 14, 1982, 3, 442 and the following.

4 BERAMENDI, Virginia et al.: Direct Democracy. The International IDEA Handbook, Stockholm 2008, 50 and the following. 
The constitutional regulation of the local referendum and assembly of municipality inhabitants under the conditions of the Slovak Republic or of other Member States of the European Union has a heterogeneous nature. Taking the fact that the Union leaves the Member States free in the regulation of local administrations, the forms of direct democracy follow various trends and specifications. Most of the Member States of the European Union have the elements of the local direct democracy directly in the constitutions to a varying extent (e.g. a brief regulation in Belgium or Portugal, or wider incorporation by content of direct democracy in Italy or Spain). Most of the states have the reference to the regulation of the organic special ruling and it is also worth noting that there are provisions defining the subject and course of the given forms. The forms of local direct democracy do not find their position in the constitutions of the states such as Denmark, Finland or the Netherlands, where the organic law plays the dominant role.

The constitutional regulation of the local referendum and assembly of a municipality inhabitants in the Slovak Republic has a special regime. In addition to the general provisions on a legal, democratic state and provisions about political rights especially in Article 67 of Act No. 460/1992 Coll., the Constitution of the Slovak Republic as amended by later regulations (hereinafter referred to as the Constitution of SR). Pursuant to Article 67 of the Constitution of SR, municipality inhabitants' assemblies shall realize a territorial self-government by local referendum, by referendum on the territory of the higher territorial unit, by municipality authorities or by higher territorial unit authorities. The manner of carrying out the local referendum or referendum on the territory of a higher territorial unit shall be laid down by a law. ${ }^{5}$

It results from the legal listing that the constitution-maker disregards purposefully the assembly of higher territorial unit's inhabitants by the reason of a larger area and high number of inhabitants of a self-governing region.

The organic law of the regulation of local referendum and a municipality inhabitants' assembly is not a special law which would exclusively regulate the areas under examination, for this purpose there is the Act on Municipal Establishment. Municipality inhabitants' assembly has no reference to a regulation by special ruling.

\section{Comparison with other legal institutes at the national level}

Both the manners of the exercise of territorial self-government resemble, by their titles and to a certain extent by their forms, another two institutes that are also incorporated in the Constitution of the Slovak Republic - nationwide referendum and public assembly. The analogy is more considerable and distinct in the case of local and nationwide referendum. The nationwide and local referendum differ by the extent of regulation in the Constitution of SR and in law. The Constitution of SR deals with referendum in its whole Section two (Articles 93 to 100) of Title Five, the local referendum is mentioned only in above mentioned Article 67, Subsection 1. The Constitution of SR, in relation to nationwide referendum and local referendum states that the manner of their carrying out shall be laid by a law. In rela-

5 Acts Nos. 369/1990 Coll. on Municipality Establishment as amended by later regulations (hereinafter as Act on Municipality Establishment) and 302/2001 Coll. on Self-Government of Higher Territorial Units (Act on SelfGoverned Regions) as amended by later regulations. 
tion to the nationwide referendum, there is Act No. 180/2014 Coll. on Conditions of Execution of the Right to Vote and on amendments to some acts. In relation to the local referendum, there is a legal regulation in the above mentioned Act on Municipal Establishment. The right to peaceful assembly is guaranteed by the Constitution in Article 28 as one of political rights. The individual legal regulation of this execution is included in Act No. 84/1990 Coll. on the Right to Assembly as amended by later regulations (hereinafter referred to the right to assembly). Despite the terminological similarity between (public) assembly and the municipality inhabitants' assembly, they are two diametrically different legal institutes. While in the case of the assembly pursuant to Article 28 of the Constitution of SR and to Act on the Right to Assemble, it is the exercise of one of the fundamental rights and can be convened for any purpose ${ }^{6}$, the municipality inhabitants' assembly is the manner of the exercise of self-government by the municipality's inhabitants. While, in relation to the public assemblies, the Constitution of SR explicitly regulate that an assembly shall not be subject to a permission of a body of public administration (Article 28, Subsection 2), the municipality inhabitants' assembly can be held on the basis of a decision of the municipal council (Article 11, Subsection 4, Paragraph f)) of the Act on Municipality Establishment). ${ }^{7}$ While a public assessment can be convened by any citizen of the Slovak Republic over the age of 18, a municipality inhabitants' assembly, following the amendment of Act on Municipality Establishment, can be convened by the municipality council or mayor of the municipality or, under certain circumstances, also by a district authority office in the seat of region. It is their reserved power. The municipality inhabitants' assembly cannot be convened by other self-government body (a council board, a commission, a municipal office) and neither can anyone else. If such assembly convened anyone else than above mentioned subjects, it would not be the assembly of municipality inhabitants pursuant to the Constitution of SR and the Act on Municipality Establishment. ${ }^{8}$

Taking into account the structure of paper, it is necessary to note here the above mentioned amendment to the Act on Municipality Establishment No. 70/2018 Coll. This amendment enlarged the list of subjects that are authorized to call a municipality inhabitants' assembly along with a municipality council. The change raised can be understood as the response to long-term discussions that refer just to this problem, while the discourse was noted both in practice as well as among theoreticians. For example Krunková9 considered the municipal council's disposal of exclusive power to call the municipality inhabitants' assembly to be the misstep of the lawmaker since other subjects were excluded and omitted at its initiation. The given author offered as possible subjects the municipality inhabitants or the council board.

6 Except for purposes that are excluded by Act on Right to Assemble in Section 10 Subsection 1.

7 From 1 April 2018, after the amendment of the Act on Municipality Establishment, the municipality inhabitants' assembly can also be called by mayor of the municipality. The municipality inhabitants' assembly can also be called by the district office in the region seat, within the territorial area of which, the non-functioning municipality is located. The municipality inhabitants' assembly is called upon the initiative of the Ministry. See details in Section 2aa of the Act on Municipality Establishment.

8 STODOLA, Dušan - DOSTÁL, Ondrej - KUHN, Ivan: Zhromaždenia obyvatel'ov obce a miestne referendá, Bratislava 2013, 3-6, online: http://samosprava.institute.sk/zhromazdenia-obyvatelov-obce-a-miestnereferenda-2013\#.WdPHu9FpHIU.

9 PALÚŠ, Igor - JESENKO, Michal - KRUNKOVÁ, Alena: Obec ako základ územnej samosprávy, Košice 2010, 184. 
The addition of district office in the region seat is clear response to a municipality malfunctioning. In my opinion, the addition of a mayor of municipality can be considered as the more considerable attribute. Since it is whole new institute, the evaluation is limited by time and it is not possible to offer the respective findings based on the application practice. I believe that this reform will bring at least polemics and discrepancies among experts for the area under examination. In my opinion, the disputes will relate, in particular, to the principle of the separation of powers among the municipality bodies, "settling things" between them, searching for an analogy with similar institutes at various levels at home and abroad. Regardless of an inducement and motive of this transformation, it is necessary to leave some time for practice and subsequently it will be possible to take a strict standpoint. The assemblies of municipality inhabitants and local referendum are regulated also by other provisions of the Act on Municipality Establishment. The Act on Municipality Establishment confers the right to elect the bodies of municipality self-government on municipality inhabitants and to be elected into the above mentioned bodies (Section 3, Subsection 2, Paragraph b)) and the right to vote about important issues of the municipality life and development (local referendum) (Section 3, Subsection 2, Paragraph b)) and the right to participate in the municipality inhabitants' assemblies and to express their opinions within the assemblies (Section 3, Subsection 2, Paragraph c)). In Section 4, Subsection 2, the Act on Municipal Establishment defines that the self-government is exercised by the municipality inhabitants through a) the municipality bodies, b) a local referendum, c) an assembly of the municipality inhabitants. A local referendum announcing is the exclusive competency of the municipal council (Section 11, Subsection 4, Paragraph f)). In relation to the local referendum, Section 11a of the Act on Municipal Establishment also regulates the reasons (particular types of facultative and obligatory referendum) and the manner of its announcing, the creation of a commission for local referendum, giving the information to qualified voters, determination of validity and the manner of announcing of the results. It is also worth noting the regulation of specific types of local referenda - in the case of merging and division of municipalities (Section 2a) and in the case of the local referendum about removal of mayor of municipality (Section 13a). The validity of the results of local referendum is regulated directly in the Act on Municipality Establishment. Pursuant to Section 11a, Subsection 9 of the Act on Municipality Establishment, the results of the local referendum are valid, if at least a half of qualified voters participated in the referendum and if the decision was taken by absolute majority of valid votes of the participants of the local referendum.

\section{Local referendum and assembly of municipality inhabitants - prac- tice and problems}

Taking into account the proved lackadaisical, stark and ambiguous polemics and the constitutional regulation which gives rise to two opinions, it is possible to divide the problem areas into two larger groups, while both the institutes under examination are concerned. For the first group the problems with constitutional aspect are typical, while the second group of problems relates to application practice. However, both the groups have, logically, the common content line. 
It is possible to consider sometimes mentioned too vague and ambiguous constitutional regulation as the most significant problem. This fact causes the obstacles in practice for the right to participate in governance by municipality inhabitants, therefore also to their chance to achieve a self-realisation and to make to adopt self-decision about the most important issues. ${ }^{10}$ I believe that failure to conduct the local referendum and assembly of municipality inhabitants gives rise to a negation of fundamental bases of democracy and self-governing. It forms the real requirement and obligation for liable entities to response such condition and to precise the position of both forms of direct democracy in the rule of order of the Slovak Republic. It is also possible to search for an inspiration in V4-countries, where the regulation is of better quality with more extensive content; the problems that are occurring in the Slovak Republic are often already solved in these countries. For example, the Czech Republic adopted the special law No. 22/2004 Coll. on Local Referendum and on amendment to several acts and made the institute of the local referendum functioning in comparison with the local conditions, removed many restrictions and thus contributed to the possibility of self-realisation of municipality inhabitants. Poland or Hungary also particularized the individual provisions relating to these institutes in the cardinal laws as well as in the laws dealing with the municipal self-government or in some special rulings.

The consequence of this negative regime under the conditions of the Slovak Republic is another problem - a disputable quorum for an initiation and subsequently of validity and effectivity of results of the local referendum. Nowadays, the loss of interest to utilize the right to participate in governance makes the initiation of a local referendum by at least $30 \%$ of qualified voters, the participation of at least half of qualified voters and the necessity to take the decision by at least absolute majority of valid votes of the participants of the local referendum the problem that is hardly to overcome. Similarly, as for the previous area, there is also relevant an inspiration taken from surrounding countries, where the quorum is lower or staggered by the municipality size. It is necessary to state that the interest to participate in governance is also small in those countries but the quorum laid down in this way could be understood as a mean for recovery of the interest about self-governance from the part of municipality inhabitants also under the conditions of the Slovak Republic.

\section{(Non)committal nature of the results}

Another key, and currently still unsolved, problem is a (non)committal nature of the result of a local referendum and of municipality inhabitants' assembly for the municipality bodies or other subjects. ${ }^{11}$ This institute is omitted by the Constitution of SR and Act on Municipality Establishment.

I think that the result of the local referendum should be obligatory for the municipality bodies. However, with respect to the existing polemics in the given area, it must be noted and highlighted the nature of direct democracy. I hold the view that the results of the forms of direct democracy have not only equivalent, but rather stronger position compared with the elements of the representative democracy. The basis of my statement consists in the principle of democracy and also in the fact that the municipality bodies come also from the result

10 The Constitutional Court of the Slovak Republic stated the similar conclusions in its judicature.

11 The situation occurred at a mayor removal by local referendum is the exception. 
of the decision of the municipality inhabitants, what is, in principle, the same mechanism of decision-making of respective subjects. The nature of the representative democracy does not mean that the municipality inhabitants give absolute power to members of municipality council for all the term without keeping any for themselves. The members and mayor are only representatives of the municipality inhabitants, they do not downgrade other forms of the exercise of the municipal self-government.

As I mentioned before, the municipality inhabitants' assembly like the local referendum, presents the significant form of direct democracy and thus it deserves the solution of the problem of (non)committal nature of the assembly result. The trend is also highlighted by the fact that the constitution-maker ranked the municipality inhabitants' assembly as number one in the list of manners of the exercise of territorial self-government. Using the analogy at the local referendum, the municipality inhabitants' assembly is the form of direct democracy that follows the same attributes and thus it deserves at least the equal respect and, logically, the binding force of the resulting decisions. The legitimacy of the decisions taken at the municipality inhabitants' assembly is also highlighted by the fact that every citizen can participate in it.

On the other hand, there are also contrary opinions, which strictly deny any committal nature of the results of the municipality inhabitants' assembly: "The Constitution of SR does not determine the legal effect of the deliberation at the municipality inhabitants' assembly. The clear legal effect is neither specified by Section 11b of Act No. 369/1990 Coll. as amended by later regulation ... The legal regulation does not determine any ratio of the municipality inhabitants that must take part in the municipality inhabitants' assembly in order they could adopt the generally binding resolutions. The legal regulation does not determine that the municipality inhabitants' assembly has the power to take a decision about a municipality issue. The resolutions adopted at the municipality inhabitants' assembly are informal, they are not connected with any legal effect. The municipality inhabitants' assembly can be assessed as the local plebiscite. The opinions presented at the municipality inhabitants' assembly can be of a recommendation nature for the municipality bodies" ${ }^{12}$ Regardless of the polemics about a committal or noncommittal nature, the municipality inhabitants' assembly and local referendum are certainly functioning, more easily organized and inexpensive ways of the exercise of municipal self-government in selected countries. Despite hardly feasible comparison of conditions in Switzerland and in the Slovak Republic, it is possible to take some inspiration also for the municipality inhabitants' assembly, in particular in the spheres which appeared in this country as suitable, purposeful and inhabitants interest-increasing.

Pursuant to Palúšs ${ }^{13}$ the problematic Section 11a of the Act on Municipality Establishment, which determines that the municipality council will announce the local referendum in the case of the municipality division, if the conditions of division specified in the Act on Municipality Establishment are fulfilled, is also worth noting. One of the conditions is connected with a necessity to have at least 3,000 inhabitants in the separated newly formed municipality. Considering the fact that the rule of law of municipalities does not regulate the obligatory number of inhabitants in any form, does not distinguish the powers of mu-

12 DRGONEC, Ján: Ústava Slovenskej republiky s komentárom, Bratislava 2004, 446-447.

13 PALÚŠ - JESENKO - KRUNKOVÁ, 150. 
nicipalities by number of inhabitants, does not deal with the financial possibilities of the exercise of self-government in municipalities with various number of inhabitants, therefore the requirement of minimum number of inhabitants 3,000 seems to be illogical, however, at the same time, it is possible to identify a non-conformance with other provisions of the Act on Municipality Establishment or with the Constitution of SR itself. ${ }^{14}$

The elimination of the disputable provision of the Act on Municipality Establishment, according to which the fact that mayor of the municipality breaks the Constitution of SR or other general binding regulations, respectively the "hard" and repeated failure to fulfill its duties is the reason for the removal of the mayor of the municipality might be considered a good step. It was more than questionable, how the members of the municipality council are capable to make a relevant legal assessment in such case.

From the point of view of the wording of the Act on Municipality Establishment, there are also other unsolved areas related to the local referendum and the municipality inhabitants' assembly. Within the framework of the problems of the local referendum, there are, for example, the affairs such as the power of the members of the municipality council to adopt the own decision after the performance of the referendum in the same affair, the institute of repeating the referendum in the same affair, the absence of the negative list of social relations, which cannot create the subject of the local referendum, many times unfeasible following of the period of 90 days $^{15}$ at the announcement of local referendum, which is carried out based on delivery of the petition of the municipality inhabitants. Within the framework of the last mentioned problem, there is a possibility how to solve the exercise of the local referendum by a body of local government.

In the constitutional regulation of the municipality inhabitants' assembly, such areas are missing at which it is possible identify the analogical features as for the local referendum. For example, the omitted institutes of repeating in the same affair, the power of members of the municipality council to adopt the own decision in the same affair after the performance of the municipality inhabitants' assembly (even wholly discordant), nonexistence of the explicit obligation of the municipality bodies to deal with the results of the municipality inhabitants' assembly, the more detailed regulation of the assembly course is also absent, etc.

The practical aspect of the local referendum and the municipality inhabitants' assembly consists in particular in insufficiently explicit constitutional regulation and in above mentioned lacks. The regulation formulated in this way in a synergy with an apathy of the municipality inhabitants connected with the governance in practice causes a rare utilization of both forms of direct democracy. ${ }^{16}$ There is also the proceeding from the part of municipalities consisting in the failure to regulate the conditions of the organization of the local referendum by a generally binding regulation. Most of the villages and towns have no such generally binding regulation. The regulation of the municipality inhabitants' assembly in

14 PALÚŠ, Igor: Uplatňovanie princípu delby moci v obecnej samospráve, in: Justičná revue, 95, 2013, 5, 659660.

15 A failure to meet the time limit based on justified reasons (the municipality council does not form a quorum during longer period of time), but also on based on a purposeful conduction from the part of members of the municipality council.

16 There are exemptions in the mentioned trend, for example Vrable town. 
municipality practice is also minimal, only in extraordinary cases there is a mention in the statutes of towns and villages or, partially, in the general binding regulations.

\section{Conclusion}

In the Slovak Republic, just as in other states, there are traces of the crisis of representative democracy. The people, whom the power comes from, clearly lose their trust in the representativeness of public authorities and in representatives, who form the authorities. The distrust does not relate only to highest public authorities in the state, but also to municipal bodies.

A change in approaches could be based, in particular, on strengthening of the institutes of direct democracy at all levels. Despite the existence of other manners of a participation of the municipality inhabitants in governance (the right of petition, requests for information, complaints and so on), in my opinion, the forms of direct democracy under examination are the most closely connected with a material core of democracy at the level of towns and villages also with the self-government functions.

However, the Act on Municipality Establishment after many amendments (including the last amendment) still considerably ignore the local referendum, but, in particular, the municipality inhabitants' assembly, what makes both institutes non-functional at the practical level. The solution of problems is to particularize the legal regulation, to add some relevant provisions into the constitutional regulation in order to avoid the discussions, unclear interpretation, a divergence in the application practice at the execution of local referendum and municipality inhabitants' assembly, a purposeful conduct of liable persons, but the main attention must be turned to the original and fundamental idea of democracy as the government and supremacy of the people in self-government, which is to have such relevant and functioning means and tools that will make it capable to intervene the administration of its affairs.

\section{References}

ALMAN, Tomáš: Miestne referendum a zhromaždenie obyvatel'ov obce ako formy priamej demokracie, in: Formy uskutočňovania obecnej samosprávy, Košice 2017, 81-90.

BERAMENDI, Virginia et al:: Direct Democracy. The International IDEA Handbook, Stockholm 2008.

DRGONEC, Ján: Ústava Slovenskej republiky s komentárom, Bratislava 2004.

KROUSE, Richard W.: Polyarchy \& Participation: The Changing Democratic Theory of Robert Dahl, in: Polity, 14, 1982, 3, 441-463, online: http://people.brandeis.edu/ woll/ krousedahl.pdf.

PALÚŠ, Igor: Uplatňovanie princípu del'by moci v obecnej samospráve, in: Justičná revue, 95, 2013, 5, 652-661.

PALÚŠ, Igor - JESENKO, Michal - KRUNKOVÁ, Alena: Obec ako základ územnej samosprávy, Košice 2010.

STODOLA, Dušan - DOSTÁL, Ondrej - KUHN, Ivan: Zhromaždenia obyvatel'ov obce a miestne referendá, Bratislava 2013, online: http://samosprava.institute.sk/zhromazde- 
nia-obyvatelov-obce-a-miestne-referenda-2013\#.WdPHu9FpHIU.

\section{Author}

PhDr. Tomáš Alman, PhD.

Katedra verejnoprávnych disciplín, Fakulta verejnej správy, Univerzita Pavla Jozefa Šafárika v Košiciach

Department of Public Law Disciplines, Faculty of Public Administration, Pavol Jozef Šafárik University in Košice

Popradská 66, 04011 Košice, Slovak Republic tomas.alman@upjs.sk 